\title{
A NOVEL APPROACH FOR SEISMIC DESIGN OF ANCHORED SHEET PILE WALL
}

\author{
Honglue Qu, Ruifeng Li, Jianjing Zhang, Huanguo Hu, Deyi Zhang
}

Original scientific paper

From investigations of damaged earth structures after earthquakes, anchored sheet pile wall has proved to be an excellent seismic structure. However, due to the complexity of the stress system, some fundamental theoretical issues have not been completely solved, so the theoretical development of the structure lags behind application, especially in the development of seismic design theory. In order to make up for this deficiency, a new simplified approach was proposed in this paper, based on previous research. In this approach, the dynamic coupling effect of the pile-soil-anchor was considered, and governing equations were established. In addition, to verify the applicability of the proposed approach, large-scale shaking table tests were performed. In the tests, similitude ratios and similar materials were appropriately applied, and horizontal and vertical acceleration time histories recorded at the Wolong station in the Wenchuan earthquake, China, were used to excite the model. Many time history curves, including dynamic and total earth pressures acting on the stabilizing pile, the cable tensions and the displacements of the wall were obtained. By comparison of the earth pressures and cable tensions between the calculations and tests, the correlation coefficient is 0,943 and 0,890 for earth pressures and cable tensions, respectively. It illustrates that the correlation coefficient between tested values and theoretical results using the proposed theoretical calculation approach is high and close to 1,0 , and it is proved that the proposed approach is suitable for practical application.

Keywords: anchored sheet pile wall; dynamic coupling effect; large-scale shaking table test; pile-soil-anchor; seismic design

\section{Novi pristup seizmičkom projektiranju ukotvljenog priboja}

Izvorni znanstveni članak

Istraživanja oštećenih zemljanih konstrukcija nakon zemljotresa pokazala su da je ukotvljeni priboj (zagat) odlična seizmička konstrukcija. Međutim, zbog složenosti sustava naprezanja, neka temeljna teorijska pitanja još nisu potpuno riješena te teorijski razvoj konstrukcije zaostaje za primjenom, posebice u razvoju teorije seizmičkog proračuna. Kako bi se nadoknadio ovaj nedostatak, u radu se predlaže novi pojednostavljeni pristup, temeljen na prethodnom istraživanju. U tom se pristupu razmatrao učinak dinamičke sprege stup (pilon, šip) - zemlja - anker (zatezač), a postavljene su i odgovarajuće jednadžbe. Uz to, kako bi se provjerila primjenjivost predloženog pristupa, provedena su opsežna ispitivanja trešenjem (shaking table tests). U tim su ispitivanjima odgovarajuće primijenjeni omjeri sličnosti i slični materijali, a podaci o vremenu horizontalnog i vertikalnog ubrzanja zabilježeni na Wolong stanici tijekom Wenchuan zemljotresa u Kini, primijenjeni su za pobuđivanje modela. Dobiveni su mnogi podaci, uključujući dinamičke i ukupne pritiske zemlje koji djeluju na stabilizacijski stup, zategnutost užadi i pomake priboja. Usporedbom pritisaka zemljane mase i zategnutosti užadi dobivenih proračunom i ispitivanjima, dobio se koeficijent korelacije od 0,943 i 0,890 za pritisak zemlje, odnosno zategnutosti užadi. To pokazuje da se primjenom predloženog pristupa postigao visoki koeficijent korelacije od gotovo 1,0 između vrijednosti dobivenih ispitivanjem $\mathrm{i}$ teorijskih rezultata, pa je dokazano da je predloženi pristup prikladan za praktične primjene.

Ključne riječi: opsežno ispitivanje trešnjom; seizmičko projektiranje; stup-zemlja-anker; učinak dinamičke sprege; ukotvljeni priboj

\section{Introduction}

A sheet pile wall is a row of interlocking, vertical pile segments installed to form an essentially straight wall to provide stability with a good margin of safety. Sheet pile walls are typically used as earth retaining structures along shorelines or slopes. There are two primary types. A cantilevered sheet pile is a wall that derives its support entirely through interaction with the surrounding soil. An anchored sheet pile is a wall that derives its support through a combination of interactions between the surrounding soil and one or more mechanical anchors, which can restrict the lateral deflection of the wall. Support from the surrounding soil for both types of walls refers primarily to the passive soil pressure exerted on the embedded section of the wall below the dredge line or bottom of the excavation [1]. In a prestressed anchor sheet pile wall, the prestress is applied in the cables. It is a type of flexible retaining structure, and has been widely used in railway, highway and other engineering fields in the past 20 years, because it is safe, reliable and has low cost. In addition, prestressed anchor sheet pile wall has been verified to be a kind of excellent seismic structure during earthquakes, as is evident from damage investigation of earth structures after the 2008 Wenchuan earthquake in China [2]. In spite of this, as a statically indeterminate structure, many fundamental theoretical issues have not been solved due to its complex stress system [3, 4].
However, geotechnical engineers prefer this structure and have used it in practice for a long time. As a result, its theoretical research greatly lags behind its practical application, especially in seismic design theory [5]. Therefore, it is significant to carry out studies of seismic design methods for prestressed anchor sheet pile wall.

Regarding the seismic design of anchored sheet pile walls, several problems have not been solved, because these types of walls are relatively new and are complex structure systems. Firstly, the dynamic deformation compatibility of pile-soil-anchor has not been clearly studied. Secondly, the dynamic coupling effect of the pile-soil-anchor has not been obtained by analytical solution. In addition, the change of the internal force of the anchor cable under ground motion has been ignored by most researchers. From the analysis models developed by previous researchers, deficiencies still exist in one or several aspects.

At present, there are some scholars engaged in the design method of anchored sheet pile walls. For instance, Babu and Basha [1] proposed a procedure for obtaining the depth and section modulus of cantilever sheet piles wall by using an inverse reliability method for the desired target component and system reliability indices. Their study did not consider the effect of the anchor tension and the soil-steel pile interface friction angle on the component. In addition, the system reliability of the anchored cantilever sheet pile walls in sandy soils was not 
studied. Basha and Babu [6] studied the stability of anchored cantilever sheet pile walls in sandy soils using reliability analysis, and an attempt was made to propose reliability-based design charts by considering the failure criteria as well as the variability in the parameters. Kim and Salgado [7] considered three target values of reliability indices to address the effect of redundancy on the internal stability checks of mechanically stabilized earth walls. Basha and Babu [8] illustrated the load resistance factor design procedure that considered the variability associated with the seismic design of reinforced soil walls. Zekri et al. [9] studied the dynamic response of anchored sheet pile quay walls that were embedded in liquefaction-susceptible soil using shaking table modeling. It is obvious that research on anchored sheet piles is becoming increasingly popular in the geotechnical field. However, existing studies on the design method have mainly focused on static conditions, rather than seismic conditions. In addition, the dynamic coupling effect of the pile-soil-anchor has not been studied much in the seismic design of this structure.

In order to improve the seismic design method, this paper proposed a simplified seismic design approach that can overcome existing deficiencies. Furthermore, the design approach was verified by the data from shaking table tests. The results show that the proposed approach is suitable for anchored sheet pile walls with prestressed cables. This study will provide a reliable basis for application of this structure in high seismic intensity zones.

\section{Methodology}

\subsection{Pile-soil-anchor dynamic coupling model}

Based on the deformation compatibility between the anchor cable and the pile under static conditions, calculation methods are often divided into two types [10]. The first type is to treat the cable tension and the landslide thrust as the given loads, and apply them directly onto the stabilizing piles, in which the stresses and deformations of the pile above and under the sliding surface are calculated, respectively, and the calculation follows the Winkler elastic foundation beam approach [11]. This calculation method is relatively simple, but the theory has an obvious deficiency [12], due to the landslide thrust calculation not considering the deformation compatibility of the anchor cables and the pile. The second method is that in the calculation of the landslide thrust action, the deformation compatibility of the anchor cables and stabilizing pile is considered, and therefore the cable tension in the work process is changed, which means that this method has considered the change of the anchor stress as a result of the landslide thrust. This method is theoretically more reasonable than the first method, but both methods do not consider the active reaction produced by the prestressed cables acting on the contact soil. The procedures ignore the fact that the earth pressure distribution has changed $[13,14]$. In addition, due to the more complex mechanism that the tension changes again under ground motion, the dynamic coupling effects of the pile-anchor-soil increase the difficulty for seismic design.
To solve the above problems, in this paper, the rigid pile was taken as an example, and several assumptions were used as follows.

(1) Simplify the stress system as a plane stress system. Assume that each anchor pile endures the pressure from the landslide thrust or the soil lateral pressure produced from a length equal to half the sum of the two adjacent pile spaces. The forces acting on the pile mainly include the landslide thrust or the soil lateral pressure, the cable tension, the reactive force of surrounding soil in the embedded section of the pile. The pile weight, the force acting on the pile bottom, the friction between the pile and the soil, and the vertical component of the earth pressures behind the wall are ignored $[15,16]$.

(2) Assume that the anchored point on the pile is an elastic hinge support, and then the anchor cable appears as elastic deformation under the force, if the linear Winkler elastic foundation beam model in the ground is used.

(3) Assume that the stabilizing pile and the anchor cables generate deformation compatibility. It illustrates that the displacement of the pile in the anchored point is equal to the cable elastic elongation.

(4) The calculation of the landslide thrust follows the basic assumption of the transfer coefficient method [17, 18 ], namely, that the seismic load used in the calculation is considered to be pseudo-static load acting on the slip mass.

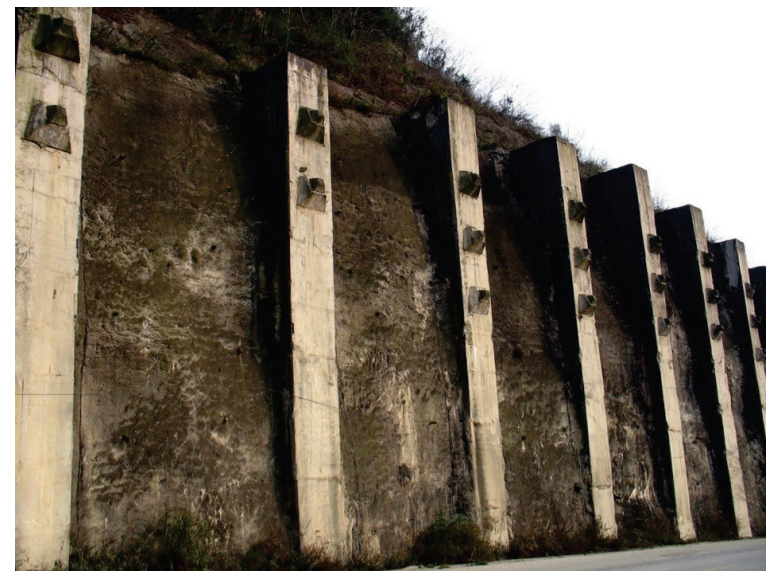

(a) Actual engineering photograph

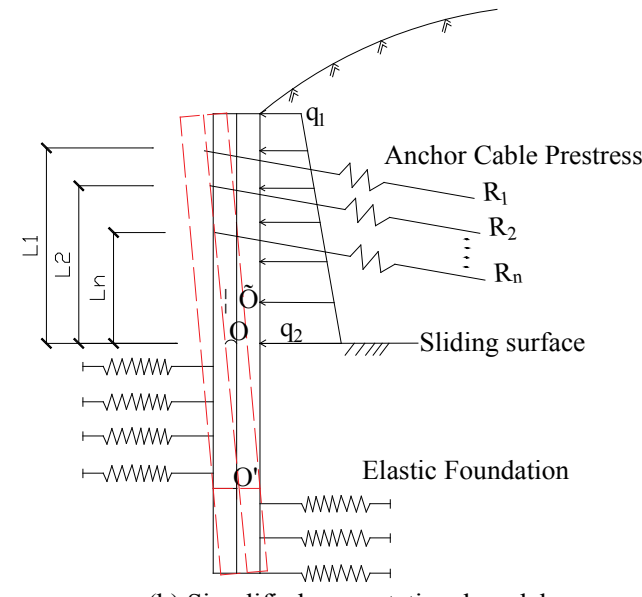

(b) Simplified computational model

Figure 1 Computational model based on actual prestressed anchor sheet pile wall

(5) Assume that the earth pressure on the back of the cantilever pile is a superposition of both the earth 
pressures produced by the landslide thrust and the cable tension, and the distribution is trapezoidal linear. In addition, the reactive force of the foundation on the back of the pile produced by the cable tension can be calculated using the Winkler elastic foundation beam method.

Based on the above assumptions, the calculation model established in this paper is shown in Figure 1.

In Fig. 1, point $\mathrm{O}$ represents the center of the embedded section of the pile, point $\mathrm{O}^{\prime}$ represents the rotation centre of the pile. $q_{1}$ and $q_{2}$ are the trapezoidal earth pressure intensities acting on the back of the pile, where $q_{1}=0$ represents a triangular distribution and $q_{1}=q_{2}$ represents a rectangular distribution. $q_{1}$ and $q_{2}$ are a superposition of the earth pressures produced by the landslide thrust and the cable tension. On the back of the pile, $q_{1}^{\prime}, q_{2}^{\prime}$ is assumed to be the earth pressure intensity produced by the cable tension at the top and sliding point, respectively, and $t_{1}, t_{2}$ is assumed to be earth pressure intensity produced by landslide thrust at the top and sliding point, respectively. The superposition process diagram is shown in Figure 2.

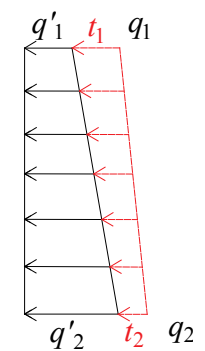

Figure 2 Superposition of earth pressures on the back of cantilever pile

\subsection{Seismic design procedure}

The detailed design and calculation steps are as follows:

(I) Only consider the role of cable tension. The Winkler elastic foundation beam method is used to calculate the distribution of the earth pressure on the back of the pile produced by the cable tension, and then the internal force equations of the pile using the existing cantilever pile method can be established.

(II) Superpose the earth pressures produced by the landslide thrust and the cable tension. By using the pseudo-static approach, the seismic landslide thrust can be added into the calculation, and the thrust is applied to the superposition of the earth pressure distribution from the back of the pile that was produced by the cable tension in step (I). The superposition result is treated as the earth pressure distribution of the back of the pile under the combined effects of the pile and anchor cables.

(III) Based on the constraint condition at bottom of the pile and the deformation compatibility principle, the equations for dealing with the cable tensions and the internal force of the pile can be established referring to the cantilever pile method.

(IV) From the above process, the established equations can be solved.

In order to illustrate the seismic design process, a cantilever pile is taken as an example. The pile is assumed to be rigid, and the constraint condition at the bottom of the pile is assumed to be free.

The steps are as follows.

\subsubsection{Anchor cable tension governing equations}

(1) Calculation of stress and deformation of the cantilever section.

Only the role of cable tension is considered, as described in Step (I). The Winkler elastic foundation beam method is used to calculate the earth pressure distribution on the back of the pile produced by the cable tension, and Eq. (1) can be established as follows.

$$
q_{1}^{\prime}=\left(y_{0}^{\prime}+h_{1}\right) \cdot B \cdot \Delta \varphi_{2} \quad q_{2}^{\prime}=y_{0}^{\prime} \cdot\left(B+m^{\prime} h_{1}\right) \cdot \Delta \varphi_{2}
$$

In the equation, $y_{0}^{\prime}$ is the depth from the turning point to the ground's surface. $\Delta \varphi_{2}$ is the angle of pile. $B$ is the elastic resistance coefficient of the slip mass at the top of the pile. $h_{1}$ is the height of the slip mass. $B+m^{\prime} h_{1}$ is the elastic resistance coefficient of the slip mass at the sliding surface.

In order to solve $y_{0}^{\prime}$ and $\Delta \varphi_{2}$ in Eq. (1), the cantilever pile method is used, in which the bending moment and shear force produced by the cable tension at point $O$ can be listed in Eq. (2) and (3), respectively.

$$
\begin{aligned}
& M_{0}^{\prime}=\sum_{j=1}^{n} R_{j} \cos \theta_{j} L_{j}-\frac{q_{1}^{\prime}+q_{2}^{\prime}}{2} \cdot h_{1} \cdot l_{1} \cdot \Delta H^{\prime}, \\
& Q_{0}^{\prime}=\sum_{j=1}^{n} R_{j} \cos \theta_{j} L_{j}-\frac{q_{1}^{\prime}+q_{2}^{\prime}}{2} \cdot h_{1} \cdot l_{1} .
\end{aligned}
$$

In these equations, $Q_{0}^{\prime}, M_{0}^{\prime}$ is the shear force and bending moment produced by the cable tension, respectively. $R_{j}$ is the peak value of cable tension in row $j$ $\theta_{j}$ is the angle between the anchor cable and the horizontal line in row $j . L_{j}$ is the height from the anchor point to point $O$ in row $j . \Delta H^{\prime}$ is the height from the position of resultant force of earth pressures to point $O$ at the sliding surface. $L_{1}$ is the calculated width of the landslide thrust or soil lateral pressure in two adjacent piles.

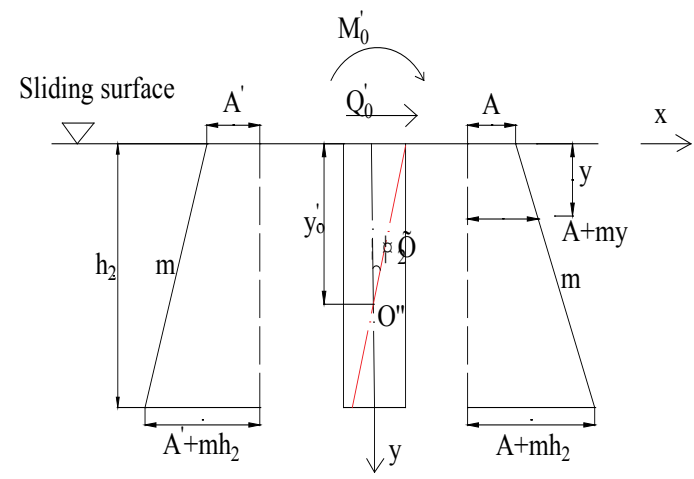

Figure 3 Configuration of the embedded section in the stratum of the elastic resistance coefficient $K=A+m y$ 
In the above process, $y_{0}^{\prime}, \Delta \varphi_{2}$ and $R_{j}$ are the basic variables. Based on the embedded section deformation condition, $y_{0}^{\prime}$ and $\Delta \varphi_{2}$ can be solved, and then based on the deformation compatibility principle, $R_{j}$ can be solved. The details of this are shown in the next step.

(2) Calculation of stress and deformation of the embedded section

Assuming that the elastic resistance coefficient $m$ below the sliding surface has the same slope change ratio, namely $K=A+m y$. In order to analyze the force on the rigid pile, the elastic resistance coefficients of the front of the pile and the back of the pile at the sliding surface are represented by $A^{\prime}$ and $A$, respectively. A schematic diagram is shown in Fig. 3.

In order to determine the depth $y_{0}^{\prime}$ of turning point $\mathrm{O}^{\prime \prime}$ and the turning angle $\Delta \varphi_{2}$, the free bottom constraint condition is used, namely, $Q_{h_{2}}^{\prime}=0, M_{h_{2}}^{\prime}=0$, and then we can obtain Eqs. (4) and (5).

$$
\begin{aligned}
& M_{0}^{\prime}+Q_{0}^{\prime} h_{2}=\frac{1}{6} B_{p} A \Delta \varphi_{2} h_{2}^{2}\left(3 y_{0}^{\prime}-h_{2}\right)- \\
& -\frac{1}{6} B_{p} A^{\prime} \Delta \varphi_{2}\left(h_{2}-y_{0}^{\prime}\right)^{3}+\frac{1}{12} B_{p} m \Delta \varphi_{2} h_{2}^{3}\left(2 y_{0}^{\prime}-h_{2}\right), \\
& Q_{0}^{\prime}=\frac{1}{6} B_{p} m \Delta \varphi_{2} h_{2}^{2}\left(3 y_{0}^{\prime}-2 h_{2}\right)+\frac{1}{2} B_{p} A \Delta \varphi_{2} y_{0}^{\prime 2}- \\
& -\frac{1}{2} B_{p} A^{\prime} \Delta \varphi_{2}\left(h_{2}-y_{0}^{\prime}\right)^{2} .
\end{aligned}
$$

In these equations, $h_{2}$ is the length of the embedded section of the pile. $B_{P}$ is the calculated width of the pile.

From Eq. (2) to Eq. (5), if $R_{j}$ is obtained, then $Q_{0}{ }^{\prime}$ and $M_{0}{ }^{\prime}$ can be calculated, and then $y_{0}{ }^{\prime}$ and $\Delta \varphi_{2}$ can be obtained. From Eq. (1), $q_{1}^{\prime}$ and $q_{2}^{\prime}$ can be obtained. The detailed process of solving $R_{j}$ is shown in step (III).

\subsubsection{Superposition of earth pressures produced by the landslide thrust and cable tension}

Only consider the action of the thrust of the landslide. Assuming that the earth pressure distribution on the back of the pile is trapezoidal and that the intensity of the earth pressure at the top of the pile is $t_{1}$, the intensity of the back of the pile at the sliding surface is $t_{2}$, the horizontal force per meter is $T$, and the height from the point of the joint action to the sliding surface is $\Delta H_{t}$, then Eq. (6) for earth pressure intensity can be established:

$q_{1}=q_{1}^{\prime}+t_{1} \quad q_{2}=q_{2}^{\prime}+t_{2}$

In the equation, $q_{1}, q_{2}$ is the earth pressure intensity at the top of the pile and the back of the pile at the sliding surface, respectively.

To solve $t_{1}$ and $t_{2}$, only considering superposition of the earth pressures on the back of the pile and the anchor cables, we can establish Eq. (7).
$M_{0}=T \cdot l_{1} \cdot \Delta H_{t}-M_{0}^{\prime}$.

In the equation, $M_{0}$ is the bending moment at point $\mathrm{O}$ under the joint actions of landslide thrust and cable tension. The solution is shown in step (III).

\subsubsection{Combined governing equations of stabilizing pile and anchor cable}

(1) Calculation of stress and deformation of the cantilever section

The equations of the bending moment and the shear force of the stabilizing pile under different external force are listed in Eqs. (8) and (9).

$$
\begin{array}{ll}
M_{0}=M-\sum_{j=1}^{n} R_{j} \cos \theta_{j} L_{j} & Q_{0}=Q-\sum_{j=1}^{n} R_{j} \cos \theta_{j} \\
M=\frac{q_{1}+q_{2}}{2} \cdot h_{1} \cdot l_{1} \cdot \Delta H & Q=\frac{q_{1}+q_{2}}{2} \cdot h_{1} \cdot l_{1} \cdot \Delta H
\end{array}
$$

In these equations, $Q_{0}, M_{0}$ is the shear force and bending moment at point $O$ under the combined effects of landslide thrust and cable tension, respectively. $Q, M$ is the shear force and bending moment at point $O$ under the earth pressures of the back of the pile, respectively, which are different from those in the static condition. $\Delta H$ is the height from the position of resultant force of earth pressures on the pile to point $O$.

To determine the value of $R_{j}$, the deformation compatibility principle is used, namely the elongation of each cable $\Delta_{i}$ is equal to the displacement of the anchored point of the pile, and then we can establish the displacement equilibrium equation, as shown in Eq. (10).

$$
\Delta_{i}=f_{i}
$$

Under an external load, after the rotation at $\mathrm{O}^{\prime}$, the pile is still in a static equilibrium state. If the rotation angle is $\Delta \varphi$, then Eq. (11) can be obtained.

$$
f_{i}=\left(y_{0}+L_{j}\right) \Delta \varphi \quad \Delta_{i}=\delta_{i}\left(R_{i}-R_{i 0}\right) \cos \theta_{i}
$$

In the equation, $\Delta \varphi$ is the angle of the pile under seismic conditions. $y_{0}$ is the depth from turning point $\mathrm{O}^{\prime \prime}$ of the rigid pile to the sliding surface (only considering the cable tension under ground motion). $\delta_{i}$ is the flexibility coefficient of cable $i, \delta_{i}=\frac{l_{i}}{N \cdot E_{g} A_{s}}$, namely, elastic elongation of the anchor cable under unit force. $l_{i}$, $A_{s}$ is the length and cross-sectional area of the free segment of each anchor cable, respectively. $E_{g}$ is the elastic modulus of the anchor cable. $N$ is the number of tenders of each anchor. $R_{i}$ is the cable tension in row $i$. $R_{i 0}$ is the tension of row $i$ under static loading.

(2) Calculation of stress and deformation of the embedded section 
Referring to step (I), by solving the depth $y_{0}{ }^{\prime}$ of turning point $\mathrm{O}^{\prime \prime}$ and turning angle $\Delta \varphi_{2}$ of the pile, we obtain Eqs. (12) and (13).

$$
\begin{aligned}
& Q_{0}=\frac{1}{6} B_{p} m \Delta \varphi h_{2}^{2}\left(3 y_{0}-2 h_{2}\right)+\frac{1}{2} B_{p} A \Delta \varphi y_{0}^{2}- \\
& -\frac{1}{2} B_{p} A^{\prime} \Delta \varphi\left(h_{2}-y_{0}\right)^{2} . \\
& M_{0}+Q_{0} h_{2}=\frac{1}{6} B_{p} A \Delta \varphi h_{2}^{2}\left(3 y_{0}-h_{2}\right)- \\
& -\frac{1}{6} B_{p} A^{\prime} \Delta \varphi\left(h_{2}-y_{0}\right)^{3}+\frac{1}{12} B_{p} m \Delta \varphi h_{2}^{3}\left(2 y_{0}-h_{2}\right) .
\end{aligned}
$$

\subsubsection{Calculation and solution}

From Eqs. (1) $\div(13)$, we can obtain the shear force, the bending moment, the distribution of earth pressures, the displacement of the pile and the cable tensions under ground motion. Although the design steps are complex and involve many equations, based on the assumptions that the stress and deformation relationships are linear, the solution is not difficult.

\section{Results}

\subsection{Shaking table experiments}

\section{(1) Test facility}

The tests were performed on a large shaking table with an advanced computer numerical controlled system, data acquisition and analysis system. The shaking table of dimensions $6 \times 6 \mathrm{~m}$, has six degrees of freedom, a maximum laden weight of 60 tonnes, a maximum horizontal displacement of $\pm 150 \mathrm{~mm}$ and a maximum vertical displacement of $\pm 100 \mathrm{~mm}$. The fully loaded horizontal and vertical maximum accelerations are $1,0 \mathrm{~g}$ and $0,8 \mathrm{~g}$, respectively, and the horizontal and vertical maximum accelerations for no loading are $3,0 \mathrm{~g}$ and $2,6 \mathrm{~g}$, respectively, with frequencies in the range $0,1 \div 80 \mathrm{~Hz}$. During the shaking table tests, a 128 channel base band modem data acquisition system with a maximum referenced error of $\leq 0,5 \%$ was used to perform data acquisition, monitor signals and provide analysis online synchronously, as shown in Fig. 4.

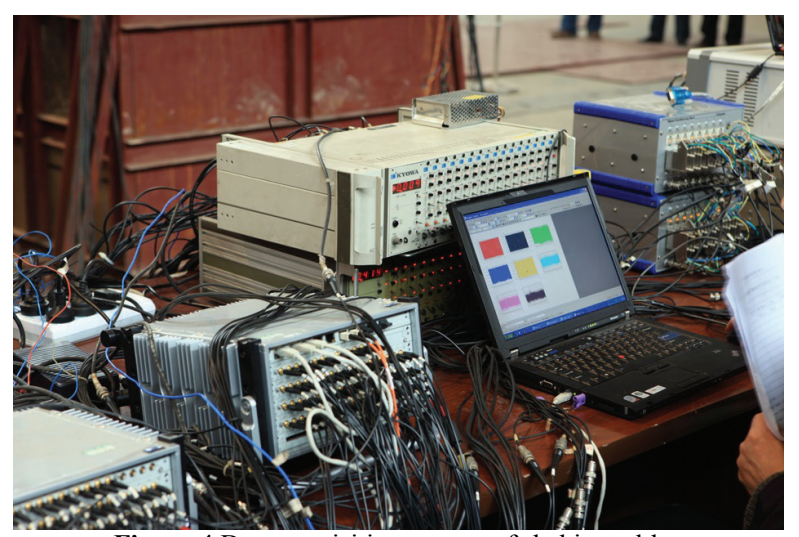

Figure 4 Data acquisition system of shaking table tests

(2) Test configuration and model construction

With a model scale of 1:10, based on Buckingham's $\pi$ theorem and by conducting dimensional analysis, the similitude ratio of each parameter can be deduced, as shown in Tab. 1.

Table 1 Similitude ratios of the test model

\begin{tabular}{|l|c|}
\hline \multicolumn{1}{|c|}{ Parameter } & Similitude ratio \\
\hline Length $(\mathrm{m})$ & 10 \\
\hline Density $\left(\mathrm{kg} / \mathrm{m}^{3}\right)$ & 1 \\
\hline Acceleration $\left(\mathrm{m} / \mathrm{s}^{2}\right)$ & 1 \\
\hline Velocity $(\mathrm{m} / \mathrm{s})$ & 3,162 \\
\hline Displacement $(\mathrm{m})$ & 10 \\
\hline Time $(\mathrm{s})$ & 3,162 \\
\hline Frequency $(\mathrm{Hz})$ & 0,316 \\
\hline
\end{tabular}

The internal size of the model box is $3,7 \times 1,5 \times 2,1$ $\mathrm{m}$, and the model box is constructed of steel frames with a steel plate on the bottom. In order to observe movement of the retaining wall and backfill, the lateral walls of the steel frame are made from synthetic glass, and absorbing material is used on the lateral walls perpendicular to the horizontal movement direction for reducing the reflection of seismic waves on the boundary. The size of the pile is $100 \times 12 \times 9 \mathrm{~cm}$, and model piles are made with a similitude ratio of 10 , with total and dynamic earth pressure sensors embedded inside the piles. The size of the model cables is $164 \times 15 \times 1,5 \mathrm{~mm}$. These cables are made of Q235 steel, which are mounted with strain gauges. The anchoring section length is $400 \mathrm{~mm}$, and the dipping angle is $15^{\circ}$. The test model is shown in Fig. 5 .

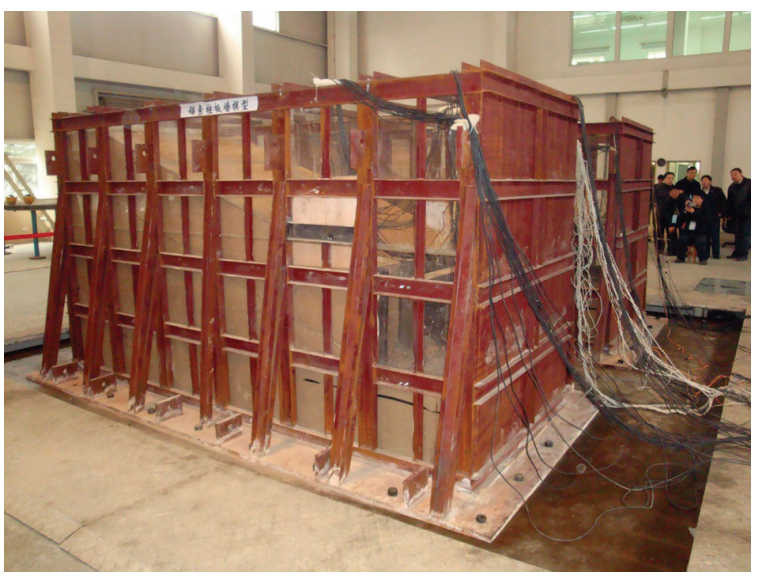

Figure 5 Photograph of the entire test model

Table 2 Material parameters of the test model

\begin{tabular}{|l|c|c|c|c|}
\hline \multicolumn{1}{|c|}{ Materials } & $\begin{array}{c}\text { Weight } \\
\text { density / } \\
\mathrm{kN} / \mathrm{m}^{3}\end{array}$ & $\begin{array}{c}\text { Liquid } \\
\text { water } \\
\text { content } \\
/ \%\end{array}$ & $\begin{array}{c}\text { Cohesion } \\
/ \mathrm{kPa}\end{array}$ & $\begin{array}{c}\text { Internal } \\
\text { friction } \\
\text { angle } /\end{array}$ \\
\hline Embedded rock & 20,3 & 3,2 & 6,92 & 38,26 \\
\hline Slip mass & 18,5 & 4 & 3,46 & 32,17 \\
\hline
\end{tabular}

As the dynamic properties of the material in the stacked layers are complex, when under low strain, the properties are nonlinear and change with the state of stress, loading frequency, duration and stress history under different conditions. The materials for the simulation are hard to configure. Considering that the sizes of the shaking table and the model box are both large, soil mixed with sand was selected as the model material for studying the dynamic response characteristics of the earth pressures [19]. In accordance with the actual situation, water, fly ash, rubber crumbs and other 
substances were added to ensure the characteristics meet the requirement of similitude. The parameters are shown in Tab. 2.

\section{(3) Instrumentation}

In the test, to ascertain the seismic response of the structure, the dynamic and total earth pressures at six levels, the displacements and accelerations of the wall at two levels, the accelerations at five levels in the backfill, and the tensions and strains of the cables were measured. The test equipment layout is shown in Fig. 6. This paper only briefly introduces the earth pressures and the tensions of the cables. The sensors were installed as shown in Figs. 7 and 8.

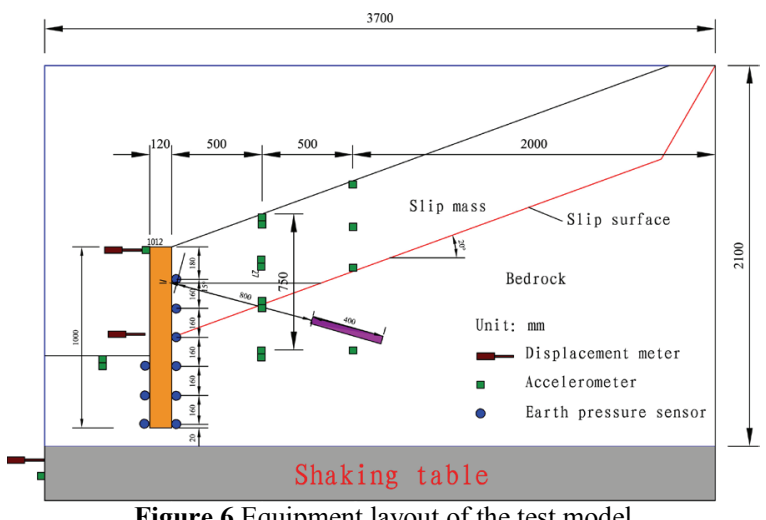

Figure 6 Equipment layout of the test model

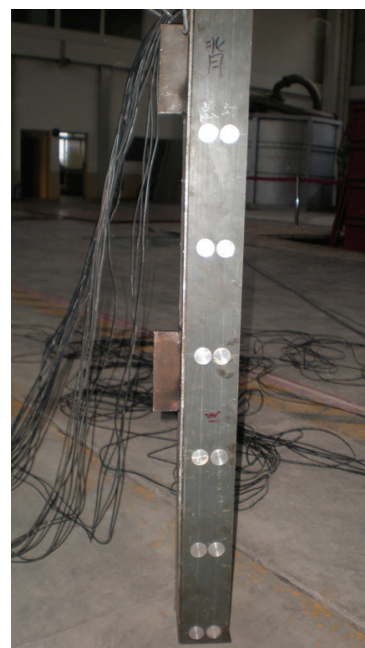

Figure 7 Earth pressure sensor installation

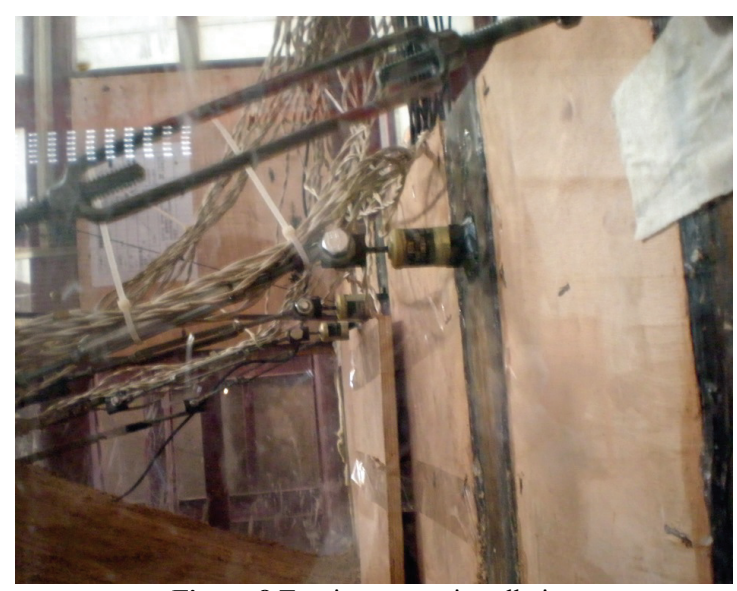

Figure 8 Tension sensor installation
(4) Input ground motion and test sequence

Horizontal and vertical accelerations recorded at the Wolong station in the Wenchuan earthquake were used to excite the model wall. Their duration was scaled according to the similitude ratio used, as shown in Fig. 9. Then, the scaled seismic accelerations were scaled again to the required amplitudes. The scaled seismic accelerations of duration and amplitude were used as input motions to excite the platform from the horizontal and vertical directions. The loading sequence in the test was white noise, time histories with peak ground accelerations $(P G A \mathrm{~s})$ of $0,1 \mathrm{~g}, 0,2 \mathrm{~g}$ and $0,4 \mathrm{~g}$.

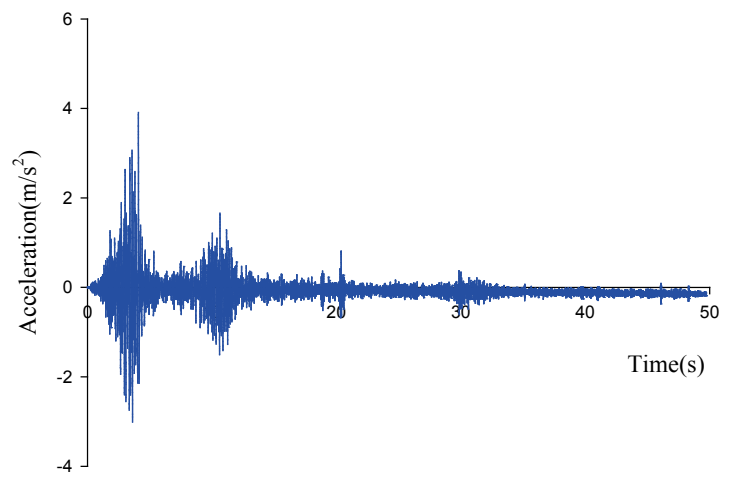

(a) Horizontal direction

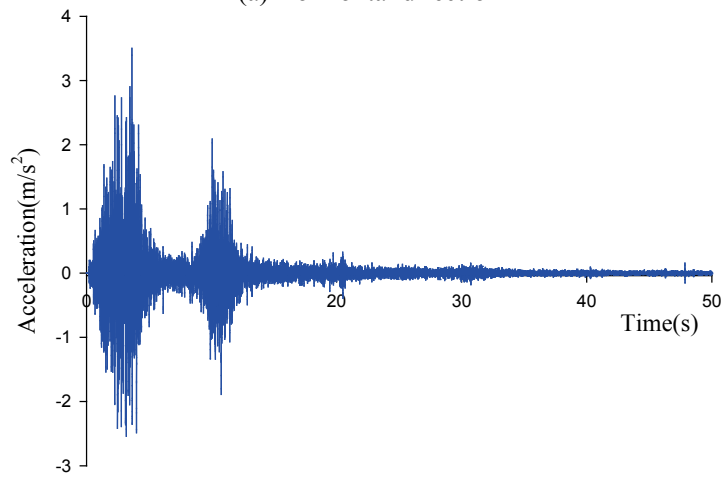

(b) Vertical direction

Figure 9 Compressed and normalized $P G A 0,4 \mathrm{~g}$ acceleration time histories recorded at Wolong station in Wenchuan earthquake

\subsection{Validation of proposed approach through experiment}

In the static condition, a comparison of earth pressure distributions from the proposed approach and the tests is shown in Fig. 10a. It is obvious that the curve calculated by the proposed approach is much closer to the measured when compared with the method in the Chinese Code [20]. The results show that in the actual anchored sheet pile wall design process, the influence of the soil reactive force produced by the cable tension should be considered.

Under the action of ground motion, in order to apply conveniently in engineering practice, seismic loads are simplified in the proposed approach. The seismic force is treated as an inertial force in the seismic calculation by using the transfer coefficient method. However, the comprehensive ground motion influence coefficient $C_{z}$ has no clear definition. Therefore, in this paper, the value of $C_{z}$ was studied by comparing with the shaking table test results. When taking the value as 0,25 (suggested value of the Chinese Code), the obtained earth pressures 
distribution are indicated by circle symbols in Figs $10 \mathrm{~b} \div$ 10 e.

The graphs show that for $P G A=0,2 \mathrm{~g}, 0,3 \mathrm{~g}$ and $0,4 \mathrm{~g}$, a $C_{z}$ value of 0,25 is suitable. For $P G A=0,1 \mathrm{~g}$, the calculated earth pressure is slightly conservative. Through several trial and error attempts, we find that for $P G A=$ $0,1 \mathrm{~g}$, taking $C_{z}$ as 0,15 , the curve of the calculated earth pressure is closer to the measured. The modified curve is shown by inverted triangle symbols in Fig. $10 \mathrm{~b}$. Therefore, for seismic design of anchored pile sheet wall, it is suggested that the comprehensive seismic influence

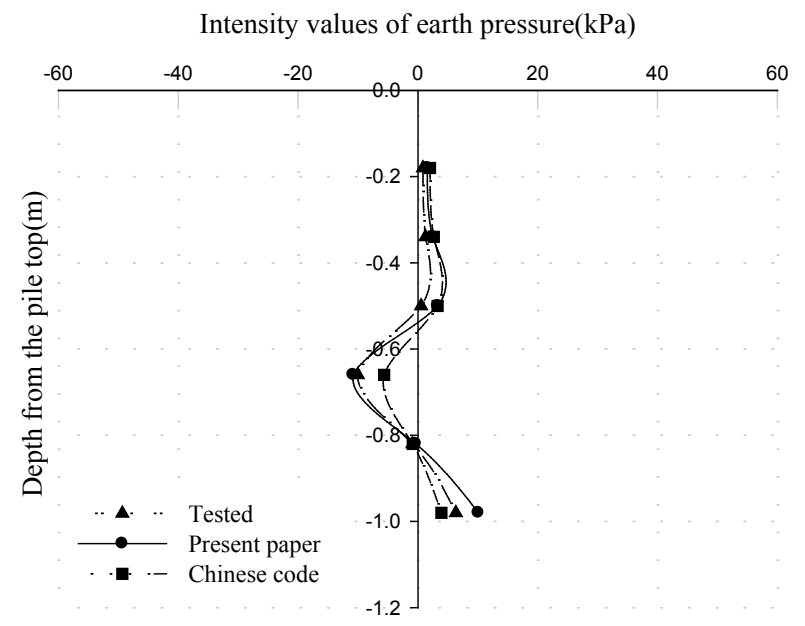

(a) Static conditions

Intensity values of earth pressure $(\mathrm{kPa})$

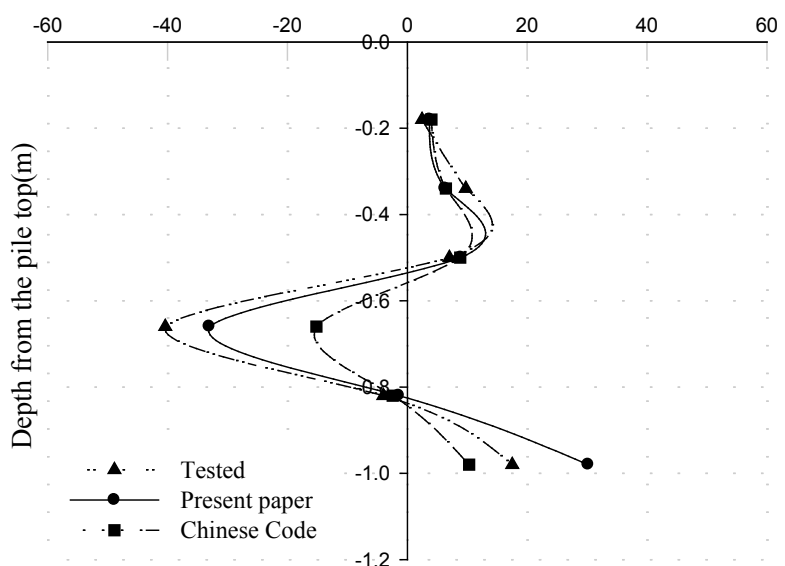

(c) $P G A=0,2 \mathrm{~g}$ coefficient $C_{z}$ is taken as 0,15 in the zones that the seismic intensity is $7^{\circ}$, and taken as 0,25 in $8^{\circ}$ and $9^{\circ}$ zones. The relationship between $P G A$ and seismic fortification intensity ruled in Chinese Code is shown in Tab. 3.

Table 3 Relationship between seismic fortification intensity and $P G A$

\begin{tabular}{|c|c|}
\hline Seismic intensity (degree) & $P G A(\mathrm{~g})$ \\
\hline 7 & $0,1(0,15)$ \\
\hline 8 & $0,2(0,3)$ \\
\hline 9 & 0,4 \\
\hline
\end{tabular}

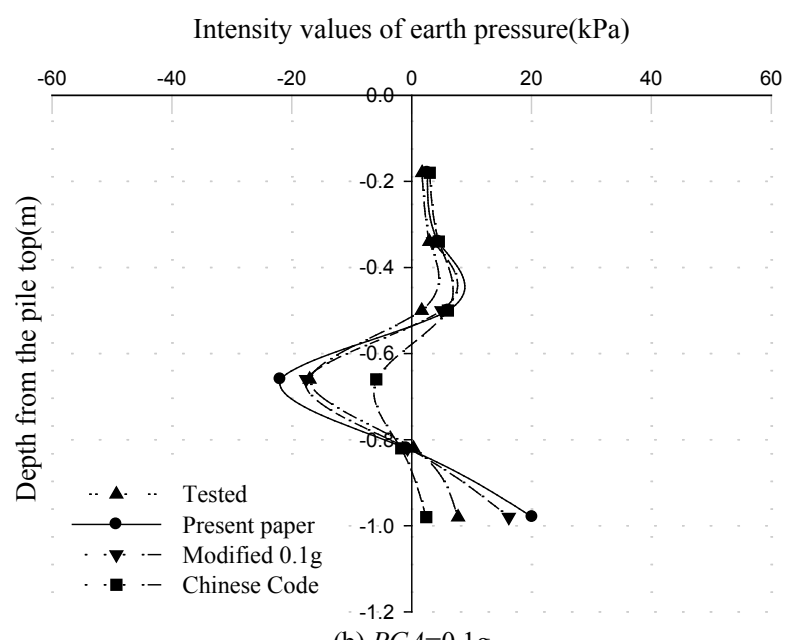

(b) $P G A=0,1 \mathrm{~g}$

Intensity values of earth pressure $(\mathrm{kPa})$

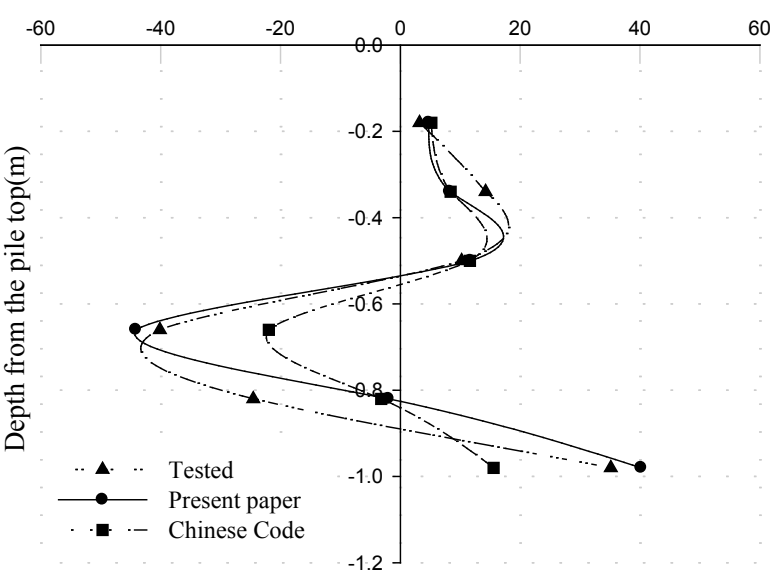

(d) $P G A=0,3 \mathrm{~g}$

Intensity values of earth pressure $(\mathrm{kPa})$

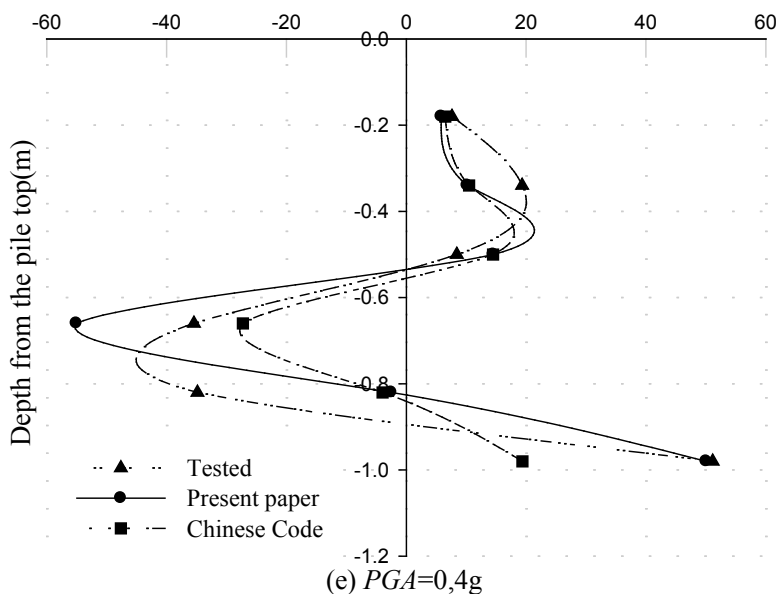

Figure 10 Comparison of measured earth pressures and theoretical results from the proposed theoretical calculation approach 
In order to determine correlation between tested values and theoretical results, correlation coefficient $r$ is applied, expressed in Eq. (14).

$$
r=\frac{\operatorname{Cov}(X, Y)}{\sqrt{D(X)} \sqrt{D(Y)}},
$$

where $\operatorname{Cov}(X, Y)$ is the covariance between theoretical results $X$ and tested values $Y$, and $D(X), D(Y)$ is variance of $X$ and $Y$, respectively.

Through Eq. (14), correlation coefficient $r$ can be obtained. Correlation coefficient between tested values and theoretical results using the proposed theoretical calculation approach is represented by $r_{1}$, and correlation coefficient between tested values and theoretical results from Chinese Code is represented by $r_{2}$. The calculation results are shown in Tab. 4

Table 4 Correlation coefficient of intensity values of earth pressure under different conditions

\begin{tabular}{|c|c|c|}
\hline Conditions & $r_{1}$ & $r_{2}$ \\
\hline Static & 0,992 & 0,940 \\
\hline$P G A=0,1 \mathrm{~g}$ & 0,965 & 0,800 \\
\hline$P G A=0,2 \mathrm{~g}$ & 0,963 & 0,977 \\
\hline$P G A=0,3 \mathrm{~g}$ & 0,931 & 0,946 \\
\hline$P G A=0,4 \mathrm{~g}$ & 0,864 & 0,857 \\
\hline Mean value & 0,943 & 0,904 \\
\hline
\end{tabular}

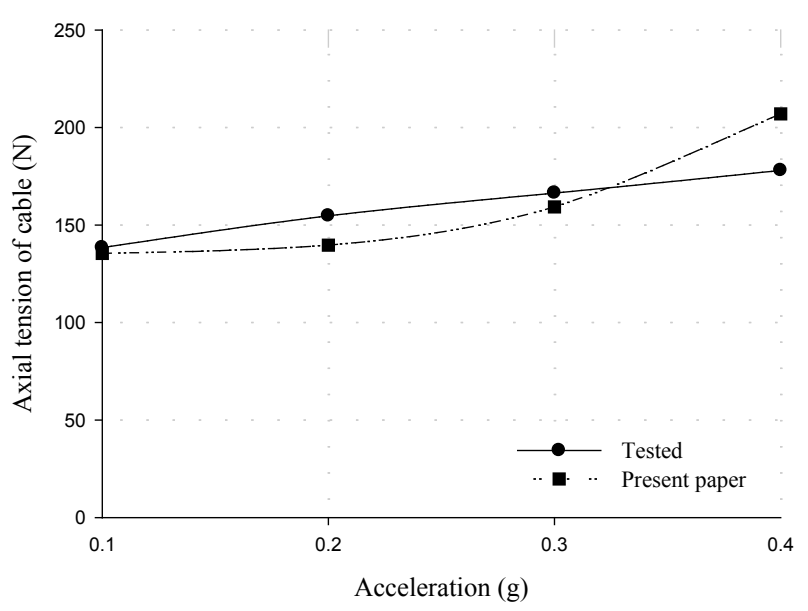

Figure 11 Comparison of measured cable tensions and calculated results by the proposed approach

In Tab. 4 , it is shown that the mean value of $r_{1}$ is equal to 0,943 . It is very high, and the values of $r_{1}$ are totally close to 1 , except the condition of $P G A=0,4 \mathrm{~g}$, while the result of 0,864 still represents high correlation between two sets of data. It means that theoretical results from the proposed theoretical calculation approach can represent actual intensity values of earth pressure. In addition, for $P G A=0,2 \mathrm{~g}, 0,3 \mathrm{~g}$ and $0,4 \mathrm{~g}$, the errors between tested values and theoretical results are little. However, for $P G A=0,1 \mathrm{~g}$, the calculated earth pressure is slightly conservative. Hence modified $C_{z}$ equal to 0,15 is proposed. It illustrates that modified $C_{z}$ is more reasonable. In Chinese Code, the soil reactive force produced by the cable tension is ignored, therefore, the calculated earth pressures are less than the measured, and this situation is risky. In addition, the correlation coefficient $r_{2}$ between tested values and theoretical results from Chinese Code is obviously smaller than $r_{1}$.

The calculated cable tensions under ground motion were compared with the test results, as shown in Fig. 11.

Through Fig. 11, the correlation coefficient between measured tensions and calculated results by proposed approach can be obtained. For all conditions, the correlation coefficient is equal to 0,890 , and it illustrates that the calculated cable tensions are close to measured. This also verifies that the proposed design approach is reasonable.

\section{Conclusion}

In order to overcome existing deficiencies in seismic design of anchored sheet pile wall, this paper proposed a simplified optimized seismic design approach. To verify the reliability of this approach, large shaking table tests have been performed, and the following conclusions were drawn through calculation and analysis.

(1) In the proposed approach, the problems of tension changes of anchor cables, the dynamic coordinate deformation problem of piles and anchor cables, and the dynamic coupling problem of the pile-anchor-rock and soil under the action of ground motion were taken into account.

(2) The mean value of correlation coefficients between tested earth pressures and theoretical results using proposed approach is 0,943 , and the values are totally close to 1,0 . It means that theoretical results can well represent actual intensity values of earth pressure.

(3) For the proposed approach, the calculation accuracy is influenced by $C_{z}$. For $P G A=0,2 \mathrm{~g}, 0,3 \mathrm{~g}$ and $0,4 \mathrm{~g}$, a $C_{z}$ value of 0,25 is suitable. However, for $P G A=0,1 \mathrm{~g}$, the calculated earth pressure is slightly conservative, therefore it is suggested that $C_{z}$ should be taken as 0.15 .

(4) The correlation coefficient between measured tensions and calculated results by proposed approach is 0,890. This also verifies that the proposed design approach is reasonable.

In conclusion, this paper has presented an optimized simplified seismic design approach and has proposed values for the comprehensive earthquake influence coefficient. Taking a cantilever rigid pile, with the bottom of the pile constraint being free as an example, the design and calculation processes have been introduced in detail. In addition, to verify the reliability of this approach, large shaking table tests have been performed. In the shaking table tests, measured earth pressure distributions and tensions were close to the calculated values, which demonstrates that this approach is applicable.

However, it should also be realized that the pileanchor dynamic interaction problem is a very complex subject. In this paper, only the case of a cantilever rigid pile, where the bottom of the pile constraint was free, was studied. Further research needs to be conducted for the case of a flexible pile, and to investigate pile-anchor seismic designs under different situations of the bottom of the pile being hinged, fixed, etc.

In addition, the test results have provided useful data for conducting further theoretical research on anchored sheet pile wall, although the data are limited in that only 
one shaking table test verified the effectiveness of the seismic design approach. There is therefore a requirement for further research.

\section{Acknowledgement}

This study was supported by the key technology research project of prevention and control for major work safety accident (2014_3189), the foundation of Education Office of Sichuan province (14ZB0056), the foundation for research and science and technology of Southwest Petroleum University (2013XJZ020), the scientific research starting project of SWPU (2014PYZ014), and the young scholars development fund of SWPU (201331010046).

\section{References}

[1] Babu, G. L. S.; Basha, B. M. Optimum design of cantilever sheet pile walls in sandy soils using inverse reliability approach. // Computers and Geotechnics. 35, 2(2008), pp. 134-143. DOI: 10.1016/j.compgeo.2007.04.001

[2] Zhang, J. J.; Qu, H. L.; Liao, Y.; Ma, Y. X. Seismic damage of earth structures of road engineering in the 2008 Wenchuan earthquake. // Environmental Earth Sciences. 65, 4(2012), pp. 987-993. DOI: 10.1007/s12665-011-1519-5

[3] Shukla, S. K.; Hossain, M. M. Stability analysis of multidirectional anchored rock slope subjected to surcharge and seismic loads. // Soil Dynamics and Earthquake Engineering. $\quad 31, \quad 5-6(2011)$, pp. 841-844. DOI: 10.1016/j.soildyn.2011.01.008

[4] Ashour, M.; Ardalan, H. Analysis of Pile Stabilized Slopes Based on Soil-Pile Interaction. // Computers and Geotechnics. 39, (2012), pp. 85-97. DOI: 10.1016/j.compgeo.2011.09.001

[5] Degrande, G.; Praet, E.; Zegbroeck, B. V.; Marcke, P. V. Dynamic interaction between the soil and an anchored sheet pile during seismic excitation. // International Journal for Numerical and Analytical Methods in Geomechanics. 26, 6(2010), pp. 605-631. DOI: 10.1002/nag.214

[6] Basha, B. M.; Babu, G. L. S. Target reliability based design optimization of anchored cantilever sheet pile walls. // Canadian Geotechnical Journal. 45, 4(2008), pp. 535-548. DOI: 10.1139/T08-004

[7] Kim, D.; Salgado, R. Load and resistance factors for internal stability checks of mechanically stabilized earth walls. // Journal of Geotechnical and Geoenvironmental Engineering. $\quad 138, \quad 8$ (2012), pp. 910-921. DOI: 10.1061/(ASCE)GT.1943-5606.0000664

[8] Basha, B. M.; Babu, G. L. S. Reliability-based load and resistance factor design approach for external seismic stability of reinforced soil walls. // Soil Dynamics and Earthquake Engineering. 60, (2014), pp. 8-21. DOI: 10.1016/j.soildyn.2014.01.013

[9] Zekri, A.; Ghalandarzadeh, A.; Ghasemi, P.; Aminfar, M. H. Experimental study of remediation measures of anchored sheet pile quay walls using soil compaction. // Ocean Engineering. 93, (2015), pp. 45-63. DOl: 10.1016/j.oceaneng.2014.11.002

[10] Ruggeri, P.; Segato, D.; Scarpelli, G. Sheet pile quay wall safety: investigation of posttensioned anchor failures. // Journal of Geotechnical and Geoenvironmental Engineering. $\quad 139, \quad 9(2013), \quad$ pp. 1567-1574. DOI: 10.1061/(ASCE)GT.1943-5606.0000886

[11] Jian, M.; Zhao, C.; Zhao, C. F.; Wang, W. Z. The bearing capacity of flexible piles under combined loads in dense sand. // Springer Geology. 62, 7(2013), pp. 173-176. DOI: 10.1007/978-3-642-31671-5_29
[12] Li, X.; Aguilar, O. Elastic earth pressures on rigid walls under earthquake loading. // Journal of Earthquake Engineering. 4, 4(2012), pp. 415-435. DOI: 10.1080/13632460009350378

[13] Bilgin, O. Numerical studies of anchored sheet pile wall behavior constructed in cut and fill conditions. // Computers and Geotechnics. 37, 3 (2010), pp. 399-407. DOI: 10.1016/j.compgeo.2010.01.002

[14] Lu, J. F.; Ye, B.; Nagaya, J. Seismic analysis of geosynthetic-reinforced quay-wall structure. // Springer Geology. 62, 7(2013), pp. 239-244. DOI: 10.1007/978-3-64231671-5_43

[15] Bastidas, A. E.; Schoefs, F. Stochastic improvement of inspection and maintenance of corroding reinforced concrete structures placed in unsaturated environments. // Engineering Structures. 41(2012), pp. 50-62. DOI: 10.1016/j.engstruct.2012.03.011

[16] Zhang, Y. J.; Li, Y. J.; Cao, W. G.; Xiao, K.; Xiang, Y. M. A study of the landslide treating methods with anti-sliding pile of h-type and pre-stressed anchor cable. // Hydrogeology and Engineering Geology. 41, 5(2014), pp. 57-63.

[17] Bi, R. N.; Ehret, D.; Xiang, W.; Rohn, J.; Schleier, M.; Jiang, J. W. Landslide reliability analysis based on transfer coefficient method: a case study from three gorges reservoir. // Journal of Earth Science. 23, 2(2012), pp. 187 198. DOI: $10.1007 / s 12583-012-0244-7$

[18] Schleier, M.; Bi, R. N.; Rohn, J.; Ehret, D.; Xiang, W. Robust landslide susceptibility analysis by combination of frequency ratio, heuristic GIS-methods and ground truth evaluation for a mountainous study area with poor data availability in the Three Gorges Reservoir area, PR China. // Environmental Earth Sciences. 71,7 (2013), pp. 3007 3023. DOI: 10.1007/s12665-013-2677-4

[19] Sitar, N. Seismic earth pressures on cantilever retaining structures. // American Society of Civil Engineers. 136, 10(2014), pp. 1324-1333.

[20] Ministry of Transport of China. Specification of seismic design for highway engineering. 1990. http://wenku.baidu.com/view/eb7041fb941 ea76e58fa0489. html. (10.25.2011).

\section{Authors' addresses}

Honglue Qu, Ph.D. (Corresponding author) Department of Geotechnical and Underground Engineering, School of Geoscience and Technology Engineering, Southwest Petroleum University, No. 8 Xindu Avenue, Chengdu, 610500, Sichuan Province, P. R. China

E-mail: swpugeoqhl@126.com

\section{Ruifeng Li, Master}

Huanguo Hu, Master

School of Civil Engineering, Southwest Petroleum University, Room A408, No. 8 Xindu Avenue, Chengdu, 610500, Sichuan Province, P. R. China E-mail: 972505312@qq.com

E-mail: $1248655462 @ q q . c o m$

\section{Jianjing Zhang, Ph.D., Professor}

Department of Geotechnical Engineering, School of Civil Engineering, Southwest Jiaotong University,

No. 111 North 1st Section of Second Ring Road, Chengdu, 610031, Sichuan Province, P. R. China

E-mail: jianzhang1102@126.com

\section{Deyi Zhang, Ph.D.}

AMEC Nuclear Safety Solutions (NSS) Limited, Canada No. 700 University Avenue, Toronto M5G1X6, Canada E-mail: zhangdyhit@gmail.com 